\title{
Mammary gland-specific ablation of focal adhesion kinase reduces the incidence of p53-mediated mammary tumour formation
}

M H A M van Miltenburg ${ }^{1,2}$, M J van Nimwegen ${ }^{1}$, I Tijdens ${ }^{1}$, R Lalai ${ }^{1}$, R Kuiper ${ }^{3}$, S Klarenbeek ${ }^{2}$, P C Schouten ${ }^{2}$, A de Vries ${ }^{4}$, J Jonkers ${ }^{2}$ and $B$ van de Water ${ }^{*}, 1$

${ }^{1}$ Division of Toxicology, Leiden/Amsterdam Center for Drug Research, Leiden University, Einsteinweg 55, P.O. Box 9502, 2300 RA Leiden, The Netherlands; ${ }^{2}$ Division of Molecular Pathology, Netherlands Cancer Institute, 1066 CX Amsterdam, The Netherlands; ${ }^{3}$ Department of Laboratory Medicine, Karolinska University Hospital Huddinge, Karolinska vägen, 17176 Solna, Sweden and ${ }^{4}$ Laboratory of Toxicology, Pathology and Genetics, National Institute for Public Health and the Environment, Antonie van Leeuwenhoeklaan 9, 3721 MA Bilthoven, The Netherlands

Background: Elevated expression of focal adhesion kinase (FAK) occurs in numerous human cancers including colon-, cervix- and breast cancer. Although several studies have implicated FAK in mammary tumour formation induced by ectopic oncogene expression, evidence supporting a role for FAK in spontaneous mammary tumour development caused by loss of tumour suppressor genes such as p53 is lacking. Alterations in the tumour suppressor gene p53 have been implicated in over $50 \%$ of human breast cancers. Given that elevated FAK expression highly correlates with p53 mutation status in human breast cancer, we set out to investigate the importance of FAK in p53-mediated spontaneous mammary tumour development.

Methods: To directly assess the role of FAK, we generated mice with conditional inactivation of FAK and p53.

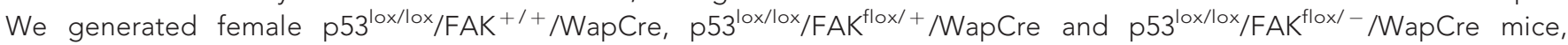
and mice with WapCre-mediated conditional expression of $\mathrm{p} 53^{\mathrm{R} 270 \mathrm{H}}$, the mouse equivalent of human $\mathrm{p} 53^{\mathrm{R} 273 \mathrm{H}}$ hot spot mutation, together with conditional deletion of FAK, $\mathrm{P} 53^{\mathrm{R} 27 \mathrm{OH} /+} / \mathrm{FAK}^{\mathrm{lox} /+} / \mathrm{WapCre}$ and $\mathrm{p} 53^{\mathrm{R} 27 \mathrm{OH} /+} / \mathrm{FAK}^{\mathrm{flox} /-} /$ WapCre mice. All mice were subjected to one pregnancy to induce WapCre-mediated deletion of p53 or expression of p53 R270H, and Fak genes flanked by two loxp sites, and subsequently followed the development of mammary tumours.

Results: Using this approach, we show that FAK is important for p53-induced mammary tumour development. In addition, mice with the mammary gland-specific conditional expression of p53 point mutation R270H, the mouse equivalent to human R273H, in combination with conditional deletion of Fak showed reduced incidence of $\mathrm{p} 53^{\mathrm{R} 270 \mathrm{H}}$-induced mammary tumours. In both models these effects of FAK were related to reduced proliferation in preneoplastic lesions in the mammary gland ductal structures.

Conclusions: Mammary gland-specific ablation of FAK hampers p53-regulated spontaneous mammary tumour formation. Focal adhesion kinase deletion reduced proliferative capacity of $\mathrm{p} 53$ null and $\mathrm{p} 53^{\mathrm{R} 270 \mathrm{H}}$ mammary epithelial cells but did not lead to increased apoptosis in vivo. Our data identify FAK as an important regulator in mammary epithelial cell proliferation in p53-

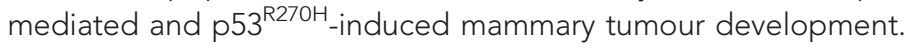

*Correspondence: Dr B van de Water; E-mail: water_b@lacdr.leidenuniv.nl

Received 3 December 2013; revised 28 March 2014; accepted 1 April 2014; published online 8 May 2014

(c) 2014 Cancer Research UK. All rights reserved 0007-0920/14 
The tumour suppressor p53 has been implicated in diverse biological processes such as apoptosis, cell-cycle arrest, DNA repair, cellular differentiation and senescence, and has been shown to be altered in over $50 \%$ of spontaneous tumours in humans (Cance et al, 2000; Wijnhoven et al, 2005; Dey et al, 2008). In addition to spontaneous tumours, germ-line mutations in p53 are observed in Li-Fraumeni patients, which predisposes them to a wide spectrum of early-onset cancers, including breast cancers (Malkin et al, 1990; Srivastava et al, 1990; Hainaut and Hollstein, 2000). Normally, p53 is expressed in a latent form and is maintained at low levels through targeted degradation. However, in response to DNA damage or stress, p53 is activated to function as a transcription factor, resulting in a cascade of events that eventually prevents tumour development. P53 is the most frequently mutated gene in spontaneous breast tumours. Approximately $30 \%$ of sporadic breast tumours acquire p53 mutations, which are related to breast cancer progression and resistance to doxorubicin therapy in breast cancer patients (Hainaut and Hollstein, 2000; Wijnhoven et al, 2005; Dey et al, 2008).

Focal adhesion kinase (FAK), a non-receptor protein tyrosine kinase, specifically associates with cell-matrix adhesions where it integrates signals from integrins and growth factor receptors to coordinate and control processes such as actin cytoskeleton dynamics and migration. Focal adhesion kinase expression is elevated in numerous cancers including colon-, cervix- and breast cancer (Cance et al, 2000; Moon et al, 2003; Lightfoot et al, 2004; Madan et al, 2006; Pylayeva et al, 2009), and FAK overexpression and p53 mutations correlate with human breast cancer (Lightfoot et al, 2004). To study the role of FAK, FAK gene knockout mice were developed but led to an embryonic lethal phenotype at day E8.5 due to defects in the axial mesodermal tissues and cardiovascular system (Ilic et al, 1995, 2003). Using conditional mouse models, the importance of FAK in skin tumour progression was shown (McLean et al, 2001), and several studies were performed to determine the role of FAK in mammary gland tumour development and progression (Lahlou et al, 2007, 2012; Provenzano et al, 2008; Luo et al, 2009; Pylayeva et al, 2009). Focal adhesion kinase deletion in MMTV-PyMT and activated ErbB2 (NDL2-5) models reduced the incidence of mammary tumours, suggesting an important role for FAK in mammary gland tumour development. PyMT is a strong proto-oncogene inducing the onset of mammary gland tumours within 10 weeks, and also ErbB2induced mammary tumours developed early, around 20 weeks (Lahlou et al, 2012). This precludes the analysis of the role of FAK in spontaneous mammary gland tumour development as a consequence of loss of heterozygosity of tumour suppressors, which is more relevant to the human situation. Consequently, these studies were unable to address the role of FAK in the natural course of mammary tumorigenesis (Lahlou et al, 2007; Provenzano et al, 2008; Luo et al, 2009; Pylayeva et al, 2009). p53 has been shown to affect FAK levels by binding to the $\mathrm{N}$-terminal region of FAK as well as to the promoter region of FAK to inhibit the transcription of FAK (Golubovskaya et al, 2008). Vice versa, FAK facilitates p53 turnover via enhanced MDM2-dependent p53 ubiquitination, and subsequent proteosomal degradation leading to inactivation of p53 (Lim et al, 2008). This mutual interaction suggests interplay in cancer development, which so far has not been investigated.

To study the role of FAK in spontaneous mammary gland tumour development, here, we used two independent spontaneous mammary tumorigenesis models that are dependent on the tumour suppressor protein p53. The first model was based on conditional deletion of the $\mathrm{p} 53$, resulting in induction of mammary tumours after 45 weeks. In the second model, we explored the contribution of FAK to mammary gland tumour development induced by a p53 point mutation $\mathrm{p} 53^{\mathrm{R} 270 \mathrm{H}}$, the mouse equivalent of human $\mathrm{p} 53^{\mathrm{R} 273 \mathrm{H}}$ mutation. Such p53 point mutation leads to dominant-negative inhibition of wild-type p53 function, and expression of mammary gland-specific $\mathrm{p} 53^{\mathrm{R} 270 \mathrm{H}}$ mutation has been shown to mimic human breast cancer development (De Vries et al, 2002). Both mouse models were crossed with conditional $\mathrm{FAK}^{\mathrm{flox} /-}$ mice and WapCre mice. Expression of the WapCre transgene is restricted to the mammary glands of late pregnant and lactating mice, and is not expressed in virgin mice (Wagner et al, 1997). Mice were subjected to one pregnancy to allow mammary-specific inactivation of both p53 and FAK. Using these two independent spontaneous mammary tumorigenesis models, we show that FAK is essential for the progression of mammary epithelial hyperplasia to mammary gland tumours caused by either loss of p53 or expression of the $\mathrm{p} 53^{\mathrm{R} 270 \mathrm{H}}$ mutant through inhibition of cell proliferation in preneoplastic lesions.

\section{MATERIALS AND METHODS}

Genotyping of mice. Genotyping of $\mathrm{p} 53^{\text {lox/lox }}$ mice was performed using the following primers. $5^{\prime}$-CAC AAA AAC AGG TTA AAC CCA G-3' [p53-int1-fwd], 5'-AGC ACA TAG GAG GCA GAG AC- $3^{\prime}$ [p53-int1-rev], $5^{\prime}$-AAG GGG TAT GAG GGA CAA GG-3' [p53-int10-fwd], 5'GAA GAC AGA AAA GGG GAG GG-3' [p53-int10-rev]. Deletion of p53 was confirmed with primers: $5^{\prime}$-CAC AAA AAC AGG TTA AAC CCA G-3' [p53-int1-fwd] and $5^{\prime}$ GAA GAC AGA AAA GGG GAG GG-3' [p53-int10-rev]. Genotyping of $\mathrm{p} 53^{\mathrm{LSL}-\mathrm{R} 270 \mathrm{H}}$ was performed using a PCR/ digestion-based assay as described previously (Wijnhoven et al, 2005). Genotyping of $f a k$ was performed using specific primers for FAK: 5'-GAGAATCCAGCTTTGGCTGTT- ${ }^{\prime}$; $5^{\prime}$-GGCTTCTTGA AGGAACTTCTC-3'; 5'-TGATATTGCTGAAGAGCTTGGCG G-3'. PCR products derived were FAK wt 88 and/or FAK mutant 170 bp; for FAK $^{\text {flox }}$ mice the primers are fwd: $5^{\prime}$-GAGAATCCAGC TTTGGCTGTTG-3', rev: 5'-GAATGCTACAGGAACC AAA TAAC-3', PCR products were Wt $290 \mathrm{bp}$ and lox $400 \mathrm{bp}$. For Cre-genotyping primers used were fwd: $5^{\prime}$-GTTCAGGGATCGC CAGGC G-3' and rev: 5'-GCTGGCTGGTGGCAGATGG-3'. Focal adhesion kinase recombination was determined using the following primers fwd: 5'-GACCTTCAACTTCTCATTTCTCC-3' and rev: 5'-GAATGCTACAGGAACCAAATAAC-3'; PCR products were Wt $1.4 \mathrm{kB}$, lox $1.6 \mathrm{kB}$ and FAK-recombined allele $327 \mathrm{bp}$. All mice were on a mixed C57jBl6/Ola background.

Analysis of spontaneous tumour development. Spontaneous tumour development was determined in $\mathrm{p} 53^{\mathrm{lox} / \mathrm{lox}} / \mathrm{FAK}^{+1+}$ $(n=25), \quad \mathrm{p} 53^{\text {lox/lox }} / \mathrm{FAK}^{\text {flox } /-}(n=25)$ and $\mathrm{p} 53^{\text {lox } / \text { lox }} / \mathrm{FAK}^{\text {flox } /+}$ $(n=25)$, and in $\mathrm{p}^{\mathrm{R}} 3^{\mathrm{R} 270 \mathrm{H}} / \mathrm{FAK}^{\mathrm{flox} /+} /$ WapCre $(n=13)$ and $\mathrm{p} 53^{\mathrm{R} 270 \mathrm{H}} / \mathrm{FAK}^{\text {flox } /-} /$ WapCre mice $(n=20)$. At the age of 8 weeks, mice were placed in breeding; pregnancy and lactation stimulated the WapCre promoter. After 3 weeks of weaning, the pups were taken away from the mother. Weight development and mammary tumour formation were monitored once a week. Mammary tumour formation was followed on a weekly basis by palpation up to 70 weeks for $\mathrm{p} 53^{\mathrm{R} 270 \mathrm{H}}$ mammary tumour development and up to 90 weeks for $\mathrm{p} 53^{\text {lox/lox }}$ mammary tumour development. Mice were killed before tumours reached the size of $1 \mathrm{~cm}^{3}$ or when mice lost more than $10 \%$ of their total body weight.

All animal experiments were approved by the local ethical committee. Housing and experiments were performed according to the Dutch guidelines for the care and use of laboratory animals (ULDEC-05099). Sterilised food and water were provided ad libitum.

Tissue processing and histology. Tumours and/or mammary glands isolated from the mice were fixed in $4 \%$ formaldehyde and subsequently processed and embedded in paraffin or snap-frozen in liquid nitrogen. Paraffin sections of $3 \mu \mathrm{m}$ were de-paraffinised, and antigen retrieval was performed when needed. Sections were stained with the primary antibody overnight at $4^{\circ} \mathrm{C}$ and with the secondary 
antibody for $1 \mathrm{~h}$ at room temperature. Slides were mounted with aqua polymount (Polysciences, Eppelheim, Germany).

Immunofluorescence microscopy and image analysis. Immunofluorescence staining was performed as described previously (De Graauw et al, 2005). Primary antibody incubation was performed overnight at $4{ }^{\circ} \mathrm{C}$, and tumours were subsequently incubated with the Alexa-488 or Cy-3-conjugated secondary antibody (Molecular Probes, Bleiswijk, The Netherlands). Microscopic analysis was performed using a Bio-Rad Radiance 2100 confocal system with a $\times 60$ or $\times 40$ Plan Apo (NA 1.4; Nikon) objective lens. Image acquisition was controlled using the Laser Sharp software (Bio-Rad, Hercules, CA, USA). Images were processed, and quantitative image analysis was performed using Image-Pro Plus (Version 5.1; Media Cybernetics, Rockville, MD, USA).

Western blot analysis. A small biopsy from the tumours was lysed using lysis buffer (Tris- $\mathrm{HCl}(10 \mathrm{~mm})$, sucrose $(250 \mathrm{~mm})$, EDTA (1 mM). Western blotting was performed as previously described (De Graauw et al, 2005). Primary antibody incubation was performed overnight at $4{ }^{\circ} \mathrm{C}$. Thereafter, blots were incubated with horseradish peroxidase-conjugated secondary antibody (GE Healthcare, Fairfield, CT, USA) or Cy5-conjugated secondary antibody in Tris-buffered saline-Tween 20 for $1 \mathrm{~h}$ at room temperature. Protein signals were detected with the ECL-plus method (GE Healthcare) followed by scanning of the blots, or, in case of Cy5 incubation, the blots were directly scanned with a Typhoon 9400 imager (GE Healthcare).

Antibodies. Anti-FAK clone 4.47, Upstate Biotechnology (Lake Placid, NY, USA) (\#05-537); anti-E-cadherin, BD transduction (San Jose, CA, USA) (\#610263); anti-vimentin, Sigma Aldrich (St Louis, MO, USA) (V-4630); anti-cytokeratin 5, Covance (Rotterdam, The Netherlands) (\#PRB-160P); anti-cytokeratin 8, Fitzgerald (North Acton, MA, USA) (rdi-pro61038); anti-p53 CM5, Novocastra (Rijswijk, The Netherlands) (p53-CM5P); anti-p21, Santa Cruz (Dallas, TX, USA) (sc-397); anti-p53 ${ }^{\text {Ser15, }}$ Cell Signaling Technology (Danvers, MA, USA) (9284); anti-Tubulin, Sigma Aldrich (T-9026); $\beta$-actin Santa Cruz (sc-47778), anti-FAK (IHC), Cell Signalling Technology (\#3258).

Gene expression analysis. Mouse mammary tumour RNA was purified using an RNeasy minikit (Qiagen, Venlo, The Netherlands). The samples were hybridised to Affymetrix microarrays. We generated mu-sigma normalised log gene expression values and clustered the mice using Euclidean distance on average linkage using $\mathrm{R}$ version 2.15 .2 and the package gplots version 2.11.0. We focused on selected basal-like genes, including Trp63, Krt17, Cryab, Ptn, Col17a1 and Slug (snai2). Genes were not reordered.

We employed principal components and hierarchical cluster analysis to determine gene expression differences in tumours derived from $\mathrm{FAK}^{+1-}$ and $\mathrm{FAK}^{-1-}$ mice in $\mathrm{R}$ version 3.0.1 (R Development Core Team).

We calculated the average expression values over all probes targeting the same gene, log-transformed and applied gene wise normalisation, resulting in a data set of 21449 probes. We used the top 10 varying genes in these analyses for visualisation. To test sensitivity to this cut-off, we checked whether results were different if top5, top25, top50 or all genes were included in the analysis (data not shown). We used 1-Pearson correlation as distance metric and Ward's method for clustering. We used BootstrapClusterTest from the ClassDiscovery package for determining the robustness of the presence of two clusters by sampling 2000 genes 200 times (Coombes, 2009).

To determine significantly differing genes between $\mathrm{FAK}^{+/-}$ and $\mathrm{FAK}^{-1-}$ tumours, we employed a two-class unpaired SAM analysis (Tibshirani et al, 2011) on $\log 10$ gene expression values of the data set.
Statistics. Survival curves were generated using Kaplan-Meier statistics. Significance was estimated using unpaired two-tailed Student's $t$-test and Log-rank (Mantel-Cox) test.

\section{RESULTS}

Mammary-specific disruption of Fak inhibits spontaneous mammary gland tumour formation in $\mathrm{p} 53^{\text {lox/lox }}$ mice. Given the importance of FAK in mammary tumour formation as shown using two independent strong oncogenes (Lahlou et al, 2007, 2012; Provenzano et al, 2008; Luo et al, 2009; Pylayeva et al, 2009) and the potential interplay of FAK and p53 in cancer, we assessed whether FAK was important in p53-mediated spontaneous mammary tumour development. We generated female WapCre/

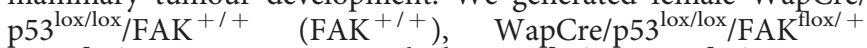
$\left(\mathrm{FAK}^{\mathrm{flox} /+}\right)$ and WapCre/p53 $3^{\text {lox/lox}} / \mathrm{FAK}^{\mathrm{flox} /-}\left(\mathrm{FAK}^{\mathrm{flox} /-}\right)$ mice. The mice were subjected to one pregnancy to induce WapCremediated deletion of $p 53$ and Fak genes flanked by two loxP sites, and subsequently followed the development of mammary tumours for a total time period of 90 weeks. The first onset of mammary tumours in $\mathrm{FAK}^{\mathrm{flox} /-}$ mice was comparable to that in $\mathrm{FAK}^{\mathrm{flox} /+}$ mice. However, mammary tumour formation reached a plateau in FAK $^{\text {flox } /-}$ mice after 60 weeks, but continued in $\mathrm{FAK}^{+/+}$and $\mathrm{FAK}^{\mathrm{flox} /+}$ animals (Figure 1A). This was reflected in the effect on the total number of mammary tumours that developed: $52 \%$ FAK $^{\text {flox } /+}$ mice developed mammary tumours (13 of a total of 25 mice), while only $\mathrm{t} 36 \% \mathrm{FAK}^{\text {flox } /-}$ mice developed mammary tumours ( 9 of a total of 25 mice) (Table 1$)$. FAK flox/ + mice were similarly susceptible for mammary tumour development compared with $\mathrm{FAK}^{+1+}$; however, $\mathrm{FAK}^{\text {flox } /-}$ mice displayed a significant difference (Figure 1A, unpaired $t$-test $P<0.05$ ). Sixty-four percent of $\mathrm{FAK}^{+1+}$ mice were mammary tumour bearing (16 of a total of 25 mice), and mean latency time for spontaneous mammary tumour development was 62 weeks for FAK ${ }^{+1+}$ mice. The mean latency time for spontaneous mammary tumour development was 67 weeks for $\mathrm{FAK}^{\text {flox/+ }}$ mice and 60 weeks for $\mathrm{FAK}^{\mathrm{flox} /-}$ mice. While contralateral mammary glands from tumour-bearing mice all displayed hyperplasia regardless of genotype, mammary glands from early and late dropouts in FAK ${ }^{\text {flox } /-}$ mice (censored events) did not display hyperplasia, indicating that these mice would not have developed mammary tumours within our experimental setting. To determine FAK recombination efficiency, mammary tumours from $\mathrm{FAK}^{\text {flox } /+}$ and $\mathrm{FAK}^{\text {flox } /-}$ mice were analysed by PCR (Figure 1B). Fak gene recombination was confirmed in FAK ${ }^{\text {flox } /+}$ and FAK flox ${ }^{-}$mammary tumours (Figure 1B). Together, these data suggest that FAK is important for p53-mediated mammary tumour development.

On the basis of their histological and structural organisation, the vast majority of mammary tumours were classified as solid carcinomas and carcinosarcomas, the latter characterised by the presence of spindle-shaped cells (Figure 1C, Table 1). Confirmatively, carcinosarcomas stained positive for vimentin and negative for E-cadherin (Supplementary Figure 1). Histological analysis of mammary glands isolated from the contralateral side of the mammary tumour revealed neoplastic or hyperplastic lesions in all groups (Figure 1C, upper panel), indicating that oncogenic transformation occurred in both FAK-expressing and FAK-deleted mammary glands.

Focal adhesion kinase-proficient and -deficient mammary tumours are genetically comparable. To test the effect of FAK gene recombination on protein level, $\mathrm{FAK}^{\text {flox/+ }}$ and $\mathrm{FAK}^{\text {flox/- }}$ and control mammary tumours $\left(\mathrm{FAK}^{+/+}\right)$were analysed for FAK protein expression. Focal adhesion kinase protein expression determined by western blot analysis and FAK staining on paraffin sections were clearly reduced in $\mathrm{FAK}^{\mathrm{flox} /+}$ and $\mathrm{FAK}^{\text {flox/- }}$ 
A

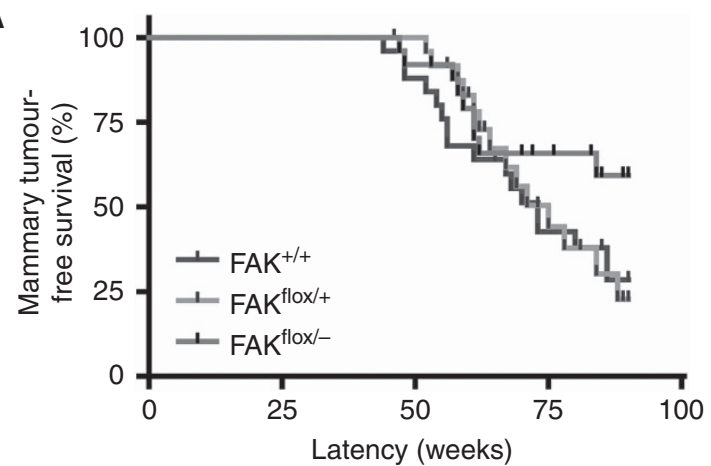

B
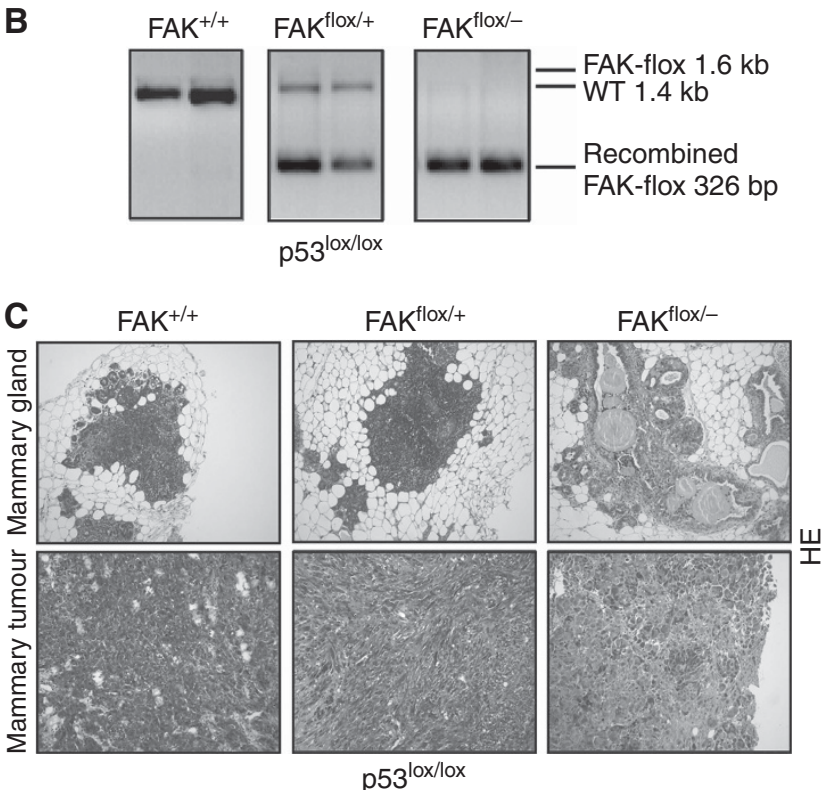

Figure 1. FAK is essential for $p 53^{\text {lox/lox }}$-induced mammary tumorigenesis. Female FAK ${ }^{+/+}(n=25), \mathrm{FAK}^{\mathrm{flox} /+}(n=25)$ and FAK $^{\text {flox } / \text { - mice }}(n=25)$ were subjected to one pregnancy to induce WapCre-mediated deletion of p53 and Fak, and subsequently followed for the development of mammary tumours for a total time period of 90 weeks. (A) Mammary tumour-free survival (\%) (Log-rank $P<0.05$, unpaired t-test $P<0.05$ ) (B) FAK recombination PCR on mammary tumours. FAK wt is $1.4 \mathrm{~kb}$, FAK lox is $1.6 \mathrm{~kb}$ and FAK recombined is $327 \mathrm{bp}$. (C) Paraffin sections of mammary tumours and non-tumourbearing mammary glands stained for hematoxylin/eosin (HE).

\begin{tabular}{|c|c|c|c|}
\hline & $\mathrm{FAK}^{+/+}$ & $\mathrm{FAK}^{\mathrm{flox} /+}$ & $\mathrm{FAK}^{\text {flox/- }}$ \\
\hline $\begin{array}{l}\text { Total number of mice } \\
\text { analysed }\end{array}$ & 25 & 25 & 25 \\
\hline Tumour-bearing mice & 18 & 14 & 11 \\
\hline Mammary gland tumour ${ }^{a}$ & $16(64 \%)$ & $13(52 \%)$ & $9(36 \%)$ \\
\hline Lymphoma & 0 & 0 & 1 \\
\hline Other ${ }^{b}$ & 2 & 1 & 1 \\
\hline $\begin{array}{l}\text { Mean mammary gland tumour } \\
\text { latency (weeks) }\end{array}$ & $61.9 \pm 12.3$ & $67.2 \pm 11.0$ & $59.7 \pm 10.7$ \\
\hline \multicolumn{4}{|c|}{$\begin{array}{l}{ }^{a} \text { The majority of mammary gland tumours that developed were characterised as solic } \\
\text { carcinomas and carcinosarcomas. } \\
\text { b Other tumours were found in the lung, bone and colon. } \\
{ }^{c} \text { Mean latency time is depicted as the number of weeks after ablation of p53 loxlox. }\end{array}$} \\
\hline
\end{tabular}
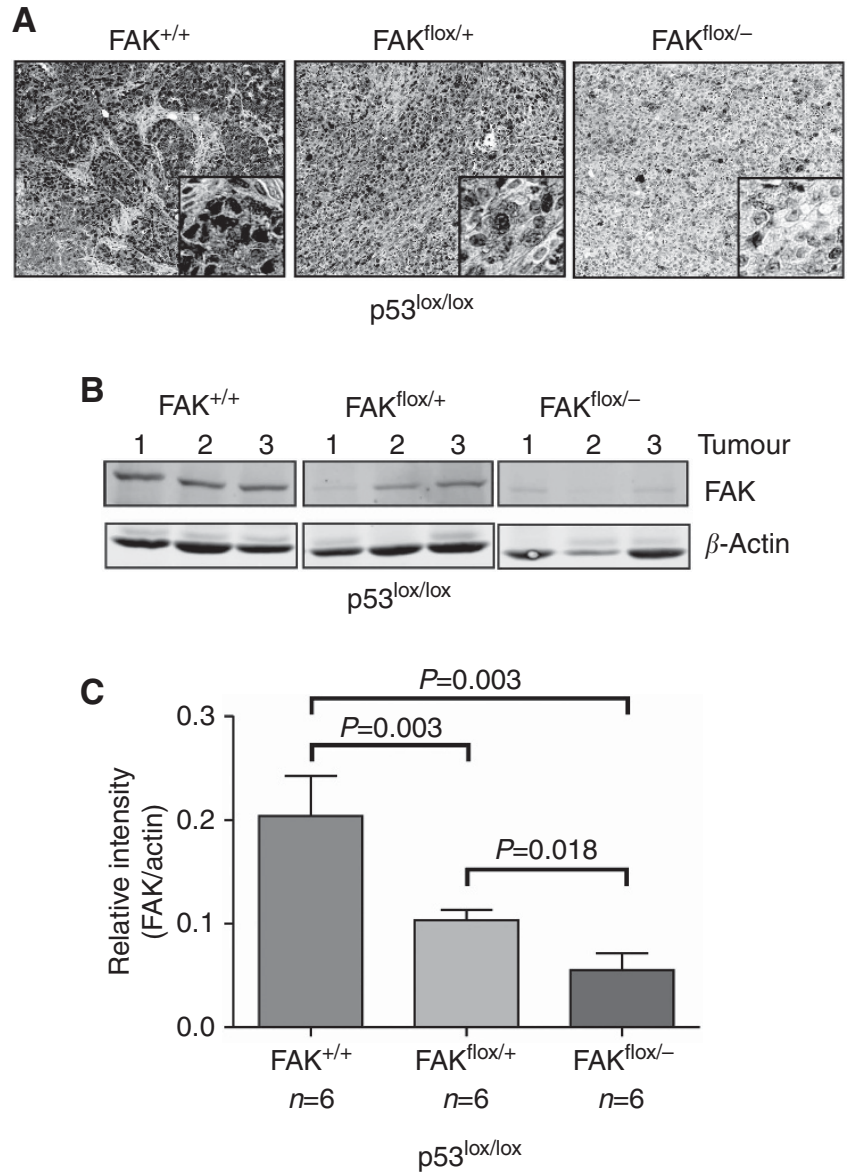

Figure 2. Fak gene recombination was successful on both gene and protein levels. (A) FAK staining on paraffin sections of mammary tumours. (B) Western blot analysis was performed on lysates of mammary tumours. Membranes were incubated with antibodies against FAK. Actin was used as a loading control. (C) Quantification of the FAK protein level. Results represent the mean of six individual tumours per genotype ( \pm s.d.), from which a representative western blot is shown in $\mathbf{B}$.

mammary tumours compared with control mammary tumours $\left(\mathrm{FAK}^{+1+}\right)$, indicating that ablation of FAK was successful on both gene and protein level (Figure $2 \mathrm{~A}-\mathrm{C}$ ). An interesting observation is that the few mammary tumours that do arise in $\mathrm{FAK}^{\text {flox } /-}$ mice share similar mammary tumour latency as compared with mammary tumour development in $\mathrm{FAK}^{\text {flox } /+}$ mice. As FAK status was significantly reduced in $\mathrm{FAK}^{\text {flox/ - }}$ mammary tumours, we wondered whether $\mathrm{FAK}^{\text {flox/ - }}$ tumours use alternative strategies to facilitate tumour development. To unravel potential alternative pathways, we performed gene expression analysis on $\mathrm{FAK}^{\mathrm{flox} /-}$ and $\mathrm{FAK}^{\text {flox } /+}$ mammary tumours. Unsupervised hierarchical clustering and principle component analysis on these tumours revealed that the $\mathrm{FAK}^{\text {flox/ - }}$ and $\mathrm{FAK}^{\text {flox } /+}$ groups do not show clear separation based on gene expression, suggesting that the mammary tumours are genetically comparable (Supplementary Figure 2). This was supported by SAM analysis to determine significant changes in gene expression between $\mathrm{FAK}^{+1-}$ and FAK $^{-1-}$ tumours, which revealed only 28 genes that showed significant higher expression in $\mathrm{FAK}^{\text {flox/+ }}$ compared with that in

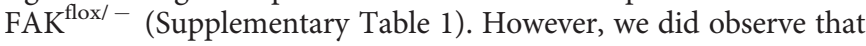
hierarchical clustering and principal components analysis identified mainly separate histological subtype, that is, solid carcinoma $v s$ carcinosarcoma, but this was not related to FAK status (Odd ratio $=3.6, P=0.34)$. One outlier sample turned out to be a lymphoma and was excluded from SAM analysis. When we 
sampled 200 times a clustering with 2000 genes (similar to visualisation, Supplementary Figure 2), we observed that the clusters were robust, with some samples from $\mathrm{FAK}^{\text {flox/ + }}$ clustering with FAK flox $/-^{-}$samples, representing similar tumour types.

Given that FAK-null mammary tumours genetically resemble FAK-proficient tumours and the sparse mammary tumours that arise show the same latency, a plausible explanation for this phenomenon is that, at the time of mammary tumour initiation and early mammary tumour development, FAK has not been deleted efficiently, which is supported by some residual cells that still showed clear FAK expression (Figure 2B).

Mammary gland-specific Fak deletion inhibits $\mathrm{p} 53^{\mathrm{R} 270 \mathrm{H}}$-induced breast tumour formation. Using the $\mathrm{p} 53^{\mathrm{lox} / \mathrm{lox}}$ mouse model, we identified a contribution of FAK in loss of tumour suppressor gene-mediated spontaneous mammary tumour formation. However, FAK overexpression in breast cancers has been frequently correlated with p53 mutations, a feature that is not represented by our $\mathrm{p} 53^{\text {lox/lox }}$ mouse model (Golubovskaya et al, 2009). Therefore, in addition to our p53 $3^{\text {lox/lox }}$ mouse model, we developed mice with WapCre-mediated conditional expression of $\mathrm{p} 53^{\mathrm{R} 270 \mathrm{H}}$, the mouse equivalent of human $\mathrm{p} 53^{\mathrm{R} 273 \mathrm{H}}$ hot spot mutation (Wijnhoven et al, 2005), together with conditional deletion of FAK. The conditional-floxed FAK strain was crossed with mice conditionally expressing $\mathrm{p} 53^{\mathrm{R} 270 \mathrm{H}}$ and WapCre to generate WapCre/p53 $1270 \mathrm{H} /+/ \mathrm{FAK}^{\mathrm{lox} /+}$ (referred to as $\mathrm{FAK}^{\mathrm{flox} /+}$ ) and WapCre/p53 $3^{\mathrm{R} 270 \mathrm{H} /+} / \mathrm{FAK}^{\text {flox/ - }}$ mice (referred to as $\mathrm{FAK}^{\mathrm{lox} /-}$ ). To evaluate the role of FAK in $\mathrm{p} 53^{\mathrm{R} 270 \mathrm{H}}$-induced mammary tumorigenesis, female $\mathrm{FAK}^{\mathrm{lox} /+}$ and $\mathrm{FAK}^{\mathrm{flox} /-}$ were subjected to one pregnancy to mediate the WapCre-mediated expression of $\mathrm{p} 53^{\mathrm{R} 270 \mathrm{H}}$ point mutation and ablation FAK. Subsequently, the mice were monitored for mammary tumour development by physical palpation for a total time period of 70 weeks. The first onset of mammary tumours was already at 38 weeks for $\mathrm{FAK}^{\text {flox/+ }}$ and 39 weeks for $\mathrm{FAK}^{\text {flox/ - }}$ after $\mathrm{p} 53^{\mathrm{R} 270 \mathrm{H}}$ induction (Figure $3 \mathrm{~A}$ and Table 2) and overall survival was similar (data not shown). Although the onset of mammary tumours was comparable, only few mammary tumours developed in $\mathrm{FAK}^{\mathrm{flox} /-}$ mice, all of which were observed within 50 weeks. The number of mammary tumourbearing mice was significantly higher in $\mathrm{FAK}^{\mathrm{flox} /+}$ mice, indicating that mice that still express FAK are more susceptible to mammary tumour development than $\mathrm{FAK}^{\mathrm{lox} /-}$ mice even later in time. Sixtynine percent ( 9 out of 13 mice) of $\mathrm{FAK}^{\text {flox } /+}$ mice were tumour bearing, all bearing one or more mammary gland tumours, with a mean latency of $51 \pm 8.3$ weeks (Figure $3 \mathrm{~A}$ and Table 2). In contrast, only 20 percent ( 4 of a total of 20 mice) of FAK flox/mice developed mammary tumours, with a mean latency of $48 \pm 8.3$ weeks, representing a clear difference in tumour formation (unpaired $t$-test $P<0.05$, Figure $3 \mathrm{~A}$ ). Most mammary gland tumours developed in the 4 th or 5 th mammary gland, $67 \%$ in FAK $^{\text {flox } /+}$ and $50 \%$ in FAK flox $/-^{-}$mice. Focal adhesion kinase recombination efficiency was determined by PCR and confirmed that FAK ablation was evident in $\mathrm{FAK}^{\operatorname{lox} /+}$ and $\mathrm{FAK}^{\mathrm{lox} /-}$ mammary tumours (Figure 3B).

On the basis of their histological analysis, mammary tumours that developed in $\mathrm{FAK}^{\mathrm{lox} /+}$ and FAK ${ }^{\mathrm{lox}} /-$ animals were mostly adenocarcinomas and solid carcinomas (Figure 3C and Table 2). Strikingly, none of the $\mathrm{p} 53^{\mathrm{R} 270 \mathrm{H}}$-driven $\mathrm{FAK}^{\mathrm{lox} /+}$ and $\mathrm{FAK}^{\mathrm{lox} /-}$ mammary tumours were classified as carcinosarcomas. P53 ${ }^{\mathrm{R} 270 \mathrm{H}}$ expression in $\mathrm{FAK}^{\mathrm{lox} /+}$ and $\mathrm{FAK}^{\mathrm{lox} /-}$ mammary tumours was assessed by immunohistochemical staining with CM5 and showed accumulation of p53 in nuclei of mammary tumour cells (Figure 4A). Accumulation of p53 was also observed in neoplastic and hyperplastic lesions of contralateral non-tumour-bearing glands (Figure 4A).We confirmed FAK protein level was reduced in $\mathrm{FAK}^{\text {flox } /-}$ mammary tumours by performing immunohistochemistry and western blot analysis (Figure 4B-D). Focal adhesion

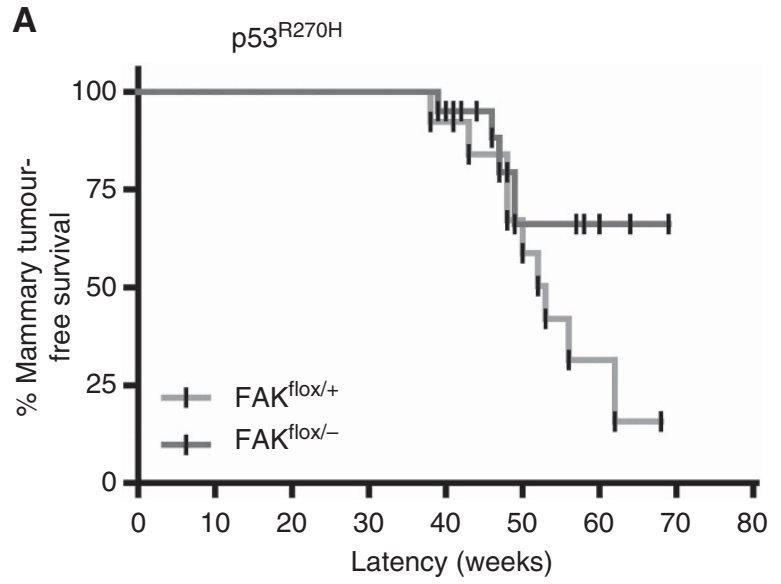

B

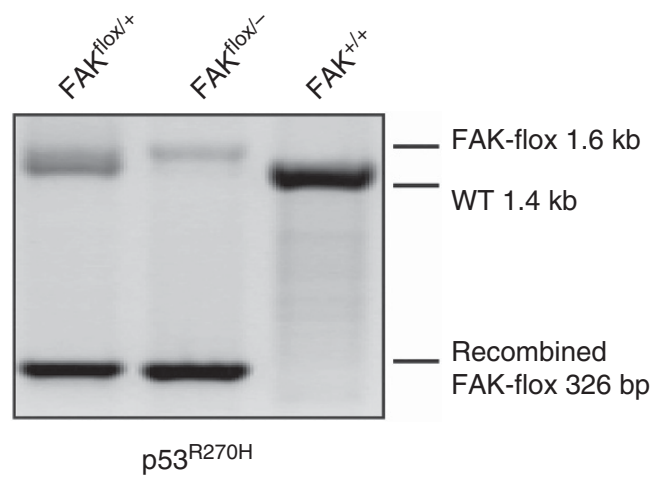

C

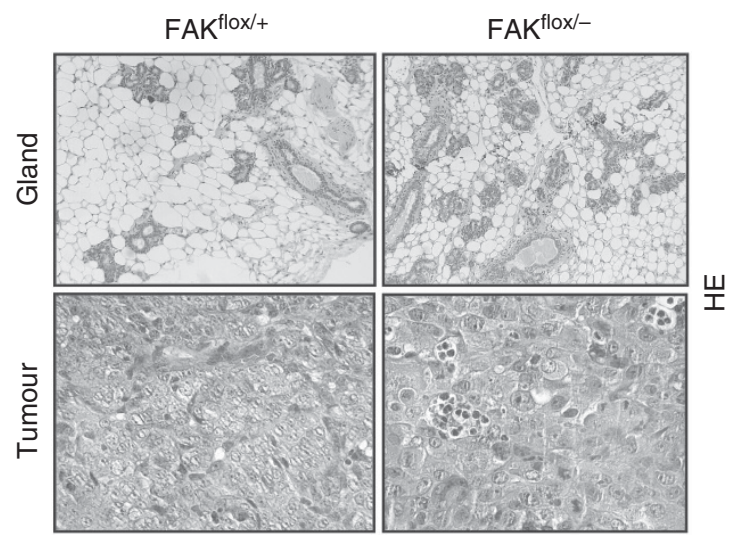

Figure 3. FAK expression is crucial for $\mathrm{p} 53^{\mathrm{R} 270 \mathrm{H}}$-induced mammary tumour progression. Female $\mathrm{p} 53^{\mathrm{R} 27 \mathrm{OH}} / \mathrm{FAK}^{\mathrm{flox} /-}$ and $\mathrm{p} 53^{\mathrm{R} 27 \mathrm{OH}} / \mathrm{FAK}^{\mathrm{flox} /+}$ mice were subjected to one pregnancy to activate WapCre resulting in the expression of $\mathrm{p} 53^{\mathrm{R} 270 \mathrm{H}}$ point mutation and deletion of the floxed Fak allele. Mice were followed for the development of mammary tumours for a total time period of 70 weeks. (A) Mammary tumour-free survival curves of p53 $3^{\mathrm{R} 27 \mathrm{OH}} / \mathrm{FAK}^{\mathrm{flox} /-}$ - WapCre $(n=20)$ and $\mathrm{p} 53^{\mathrm{R} 270 \mathrm{H}} /$ FAK $^{\text {flox/ }}+$ WapCre mice $(n=13)$. Time is depicted in weeks after $\mathrm{p} 53^{\mathrm{R} 270 \mathrm{H}}$ expression, set at time of birth of litters (Log-rank ns, unpaired t-test $P<0.05$ ). (B) FAK recombination $P C R$ was used to determine recombination of the FAK allele flanked by loxP sites. FAK wt is $1.4 \mathrm{~kb}$, FAK lox is $1.6 \mathrm{~kb}$ and FAK recombined is $327 \mathrm{bp}$.

(C) Mammary tumours were stained with haematoxylin/eosin (HE) to determine tumour type.

kinase staining on paraffin sections of the isolated tumours showed a manifest reduction in FAK protein levels in $\mathrm{FAK}^{\text {flox/ - }}$ tumours (Figure 4B), indicating that in our model FAK is successfully deleted. However, in line with the observations made in $\mathrm{p} 53^{\text {lox/lox }}$ mouse model, we obtained several mammary tumours that lack 
FAK but show similar tumour latency compared with FAK $^{\text {lox/ + }}$ mammary tumours. Unfortunately, the low number of tumours obtained from $\mathrm{FAK}^{\text {flox } /-}$ mice in $\mathrm{p} 53^{\mathrm{R} 270 \mathrm{H}}$ model does not permit a further robust genetic comparison.

In conclusion, our data indicate that FAK is important for p53 $3^{\text {lox/lox }}$ and $\mathrm{P} 53^{\mathrm{R} 270 \mathrm{H}}$-induced spontaneous mammary tumour development.

Mammary-specific ablation of FAK results in a remarkable reduction in proliferation of $\mathrm{p} 53^{\mathrm{lox} / \mathrm{lox}}$ and $\mathrm{p} 53^{\mathrm{R} 270 \mathrm{H}}$ cells in neoplastic lesions. We have previously shown that FAK ablation affects mammary gland development and inhibits the lactational differentiation process (Van Miltenburg et al, 2009). Other studies indicate a role for FAK in tumour-cell proliferation (Lahlou et al, 2007; Provenzano et al, 2008). Deletion of FAK did not affect the

\begin{tabular}{|c|c|c|}
\hline \multicolumn{3}{|c|}{ Table 2. Tumour spectrum in $\mathrm{FAK}^{\mathrm{flox} /+}$ and $F A K^{\mathrm{flox} /-} \mathrm{p} 53^{\mathrm{R} 270 \mathrm{H}}$ mice } \\
\hline & $\mathrm{FAK}^{\text {flox/+ }}$ & $\mathrm{FAK}^{\mathrm{flox} /-}$ \\
\hline Total number of mice analysed & 13 & 20 \\
\hline Tumour-bearing mice & 9 (69\%) & $9(45 \%)$ \\
\hline Mammary gland tumour & $9(69 \%)$ & $4(20 \%)$ \\
\hline Carcinoma $^{a}$ & 9 & 4 \\
\hline Lymphoma & 0 & 1 \\
\hline Other $^{\mathbf{b}}$ & 0 & 5 \\
\hline Mean mammary gland tumour latency (wks) ${ }^{c}$ & $51 \pm 8.3$ & $48 \pm 8.3$ \\
\hline \multicolumn{3}{|c|}{$\begin{array}{l}{ }^{a} \text { Carcinomas could be classified in adenocarcinoma and solid carcinomas. } \\
b^{b} \text { Other tumours were found in the lung, bone, and colon. } \\
{ }^{c} \text { Mean latency time is depicted as the number of weeks after expression of the } p 53^{\mathrm{R} 27 O H} \\
\text { mutation. }\end{array}$} \\
\hline
\end{tabular}

growth rate of tumours after they appeared in either $\mathrm{p} 53^{\text {lox/lox }}$ or p53 ${ }^{\mathrm{R} 270 \mathrm{H}}$ background: typically, after detection by palpation all tumours reached a volume of $1 \mathrm{~cm}^{3}$ within a few days. Therefore, to determine the role of FAK in mammary tumour development in our models, we quantified the proliferative potential by staining for Ki67 in mammary glands that contained neoplastic and hyperplastic lesions, while no tumour was detected yet. In p53 $3^{\text {lox/lox }}$ and p53 $3^{\mathrm{R} 270 \mathrm{H}}$ mice neoplastic and hyperplastic lesions were evident already at 40 weeks, corresponding to early phases of oncogenic transformation. P53 $3^{\text {lox/lox}} / \mathrm{FAK}^{\text {flox/ }}$ - mammary glands showed a significant reduction in ki67-positive cells compared with p53 $3^{\text {lox/lox }} / \mathrm{FAK}^{+1+}$ and $\mathrm{p} 53^{\mathrm{lox} / \mathrm{lox}} / \mathrm{FAK}^{\text {flox } /+}$ mammary glands (Figure $5 \mathrm{~A}$ and $\mathrm{C}$ ), while number of apoptotic cells, determined by cleaved caspase-3, was comparable in all groups (Supplementary Figure 3). Confirmatively, reduced proliferation was also observed in $\mathrm{p} 53^{\mathrm{R} 270 \mathrm{H} /+} / \mathrm{FAK}^{\mathrm{flox} /-}$ mammary glands, albeit not significant, which is related to the limited number of $\mathrm{p} 53^{\mathrm{R} 270 \mathrm{H}} / \mathrm{FAK}^{\text {flox/ }}$ tumours $(n=4)$, suggesting that also during mammary tumour development FAK is important for proliferation (Figure $5 \mathrm{~B}$ and $\mathrm{D}$ ). Taken together, these observations indicate that FAK is required at early stages of tumour initiation but becomes dispensable for expansion of established tumours.

Deletion of FAK does not influence tumour type. P5 $3^{\mathrm{R} 270 \mathrm{H}}$ mice develop mammary tumours that, based on their histomorphological characteristics, did not resemble the mammary tumours that arose in $\mathrm{p} 53^{\text {lox/lox }}$, and mammary tumour latency was significantly shorter in $\mathrm{P} 53^{\mathrm{R} 270 \mathrm{H}} / \mathrm{FAK}^{\mathrm{lox} /+}$ mice compared with $\mathrm{p} 53^{\mathrm{lox} / \mathrm{lox}} /$ $\mathrm{FAK}^{\mathrm{lox} /+}$ (Supplementary Figure 4A). In human breast cancers, an inverse correlation has been observed between p53 activity and FAK expression. As $\mathrm{P} 53^{\mathrm{R} 270 \mathrm{H}} / \mathrm{FAK}^{\mathrm{lox} /+}$ tumours had a shorter latency than $\mathrm{p} 53^{\text {lox/lox}} / \mathrm{FAK}^{\mathrm{lox} /+}$ tumours, we determined whether this effect could be explained by differences in the FAK protein level. Indeed $\mathrm{P} 53^{\mathrm{R} 270 \mathrm{H}} / \mathrm{FAK}^{\mathrm{lox} /+}$ tumours show a significant higher FAK protein level (Supplementary Figure 4B and C),
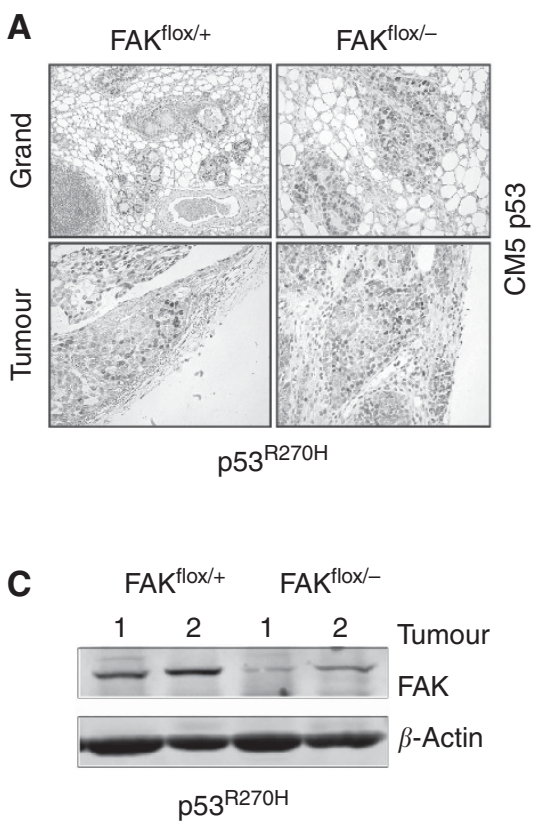

B

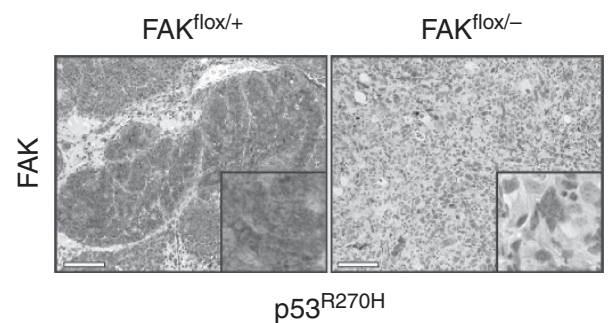

D

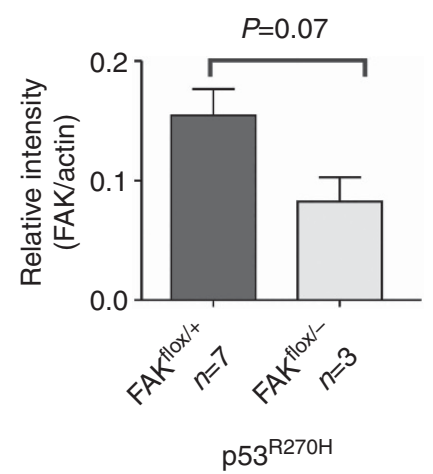

Figure 4. Successful p53 and Fak gene recombination in $\mathrm{p} 53^{\mathrm{R} 270 \mathrm{H}} / \mathrm{WapCre}$ mice. (A) Mammary glands and tumours were stained with $\mathrm{p} 53 \mathrm{CM} 5$ to validate $\mathrm{p} 53$ accumulation, which confirms $\mathrm{p} 53^{\mathrm{R} 27 \mathrm{OH}}$ expression. (B) FAK staining on paraffin sections of mammary tumours. Sections were analysed by light microscopy. (C) Western blot analysis was performed on mammary tumour lysates to determine the FAK protein level. (D) Quantification of FAK protein level. Results represent the mean of seven and three individual tumours from $\mathrm{p} 53^{\mathrm{R} 27 \mathrm{OH}} / \mathrm{FAK} \mathrm{Flox}^{+}+$and $\mathrm{p} 53^{\mathrm{R} 270 \mathrm{H}} /$ $\mathrm{FAK}^{\mathrm{flox} /-}$, respectively ( $\left.\pm \mathrm{SD}\right)$, from which a representative western blot is shown in $\mathrm{C}$. 
A

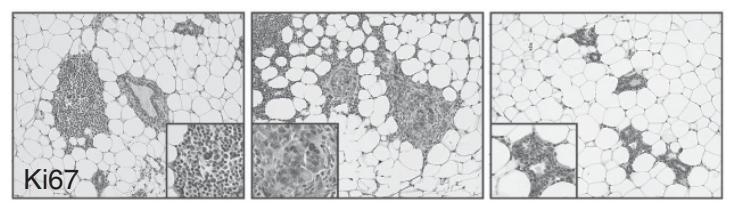

p53 $3^{\operatorname{lox} / 10 x}$

C

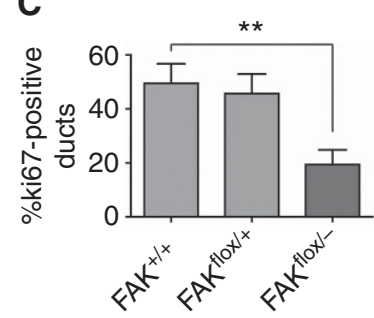

p53 $3^{\text {lox/lox }}$

E

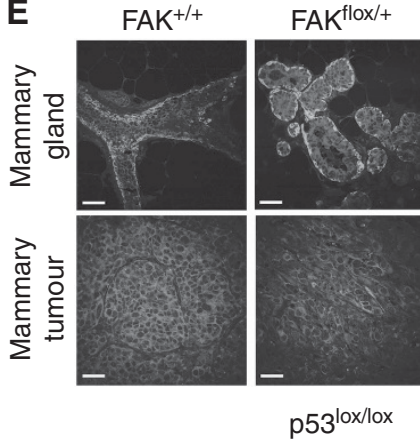

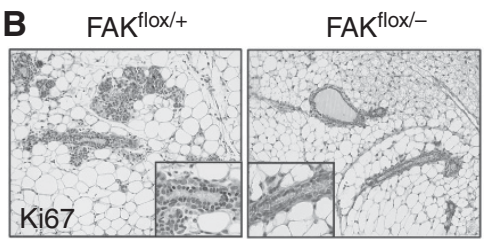

$\mathrm{p} 53^{\mathrm{R} 270 \mathrm{H}}$

D

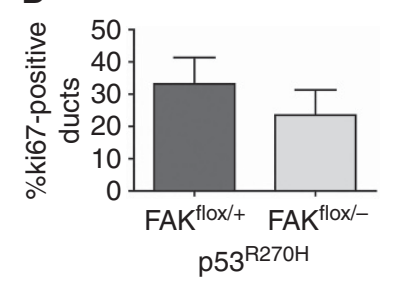

$\mathbf{F}$

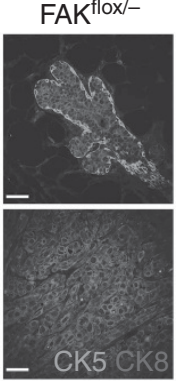

(2)

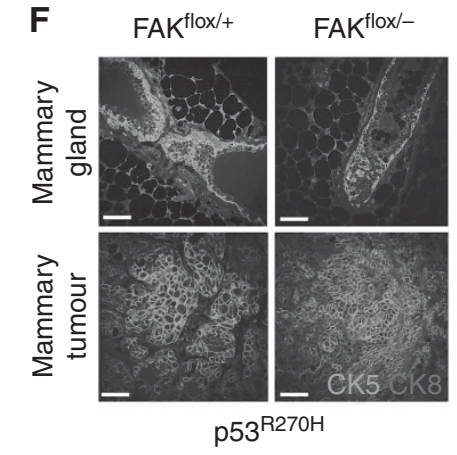

Figure 5. Mammary-specific ablation of FAK leads to reduced proliferation in preneoplastic ductal lesions. (A, B) Mammary glands from p53 lox/

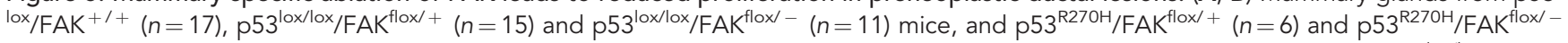
$(n=15)$ mice, obtained over the course of the experiment, were stained for the proliferation marker Ki67. (C, D) Percentage of P53 ${ }^{\text {lox/lox }}(P<0.01)$ and $\mathrm{p} 53^{\mathrm{R} 27 \mathrm{OH}}$ ductal structures containing $\mathrm{Ki} 67^{+}$mammary epithelial cells. Five $\mathrm{p} 53^{\mathrm{R} 27 \mathrm{OH}} / \mathrm{FAK} \mathrm{K}^{\mathrm{flox} /}$ - mammary glands were excluded as they did contain too few ductal structures to quantify the ki67-positive cells. (E, F) Paraffin sections of p53 lox/lox and p53 ${ }^{\mathrm{R} 270 \mathrm{H}}$ mammary tumours and nontumour-bearing mammary glands were stained for luminal marker cytokeratin 8 (CK8) and myoepithelial marker cytokeratin 5 (CK5). Fluorescent staining was analysed by confocal laser scanning microscopy. Scale bar is $50 \mu \mathrm{m}$.

indicating that mammary tumour formation is dose dependent. This observation is in line with data showing a correlation between FAK protein level and p53 mutations (Golubovskaya et al, 2009).

Next, we wondered whether $\mathrm{P} 53^{\mathrm{R} 270 \mathrm{H}} / \mathrm{FAK}^{\mathrm{lox} /+}$ mice develop from the same mammary epithelial progenitors. WapCre is activated predominantly in the luminal compartment (Wagner et al, 1997). To determine whether the mammary tumours developed from the luminal-epithelial compartment, we stained all $\mathrm{P} 53^{\mathrm{R} 270 \mathrm{H}}$-driven and $\mathrm{p} 53^{\mathrm{lox} / \mathrm{lox}}$-induced mammary glands and tumours for cytokeratin 8 (CK8), a luminal marker, and cytokeratin 5 (CK5), a myoepithelial or basal marker. In contralateral non-tumour-bearing $\mathrm{p} 53^{\text {lox/lox }}$ mammary glands (Figure 5E), expansion of the CK8-positive luminal compartment was evident. Also, with exception of one $\mathrm{FAK}^{+/+}$mice, all tumours were $\mathrm{CK} 8$ positive (Figure 5E), indicating that the tumours developed from the luminal compartment. Interestingly, p $53^{\mathrm{R} 270 \mathrm{H} /+}$-expressing mammary glands show expansion of CK5and CK8-positive epithelial cells upon expression of $\mathrm{p} 53^{\mathrm{R} 270 \mathrm{H}}$ (Figure 5F), and mammary tumours that ultimately develop in $\mathrm{p}_{5} 3^{\mathrm{R} 270 \mathrm{H} /+} / \mathrm{FAK}^{\mathrm{lox} /+}$ and $\mathrm{p} 53^{\mathrm{R} 270 \mathrm{H} /+} / \mathrm{FAK}^{\mathrm{lox} /-}$ animals were predominantly CK5 positive (Figure $5 \mathrm{~F}$ ). These observations were independent of FAK background. These data suggest that $\mathrm{p} 53^{\mathrm{R} 270 \mathrm{H}}$ induces tumours with basal-like characteristics, which are strikingly different from the mammary tumours developed in the p53 $3^{\text {lox/lox }}$ mouse model, as the p $53^{\text {lox/lox }}$ mouse model only gave rise to CK8-positive tumours. Cytokeratin 5 status was confirmed by western blot analysis, again clearly indicating that mammary tumours that developed in the $\mathrm{p} 53^{\mathrm{R} 270 \mathrm{H}}$ mouse model were CK5 positive (Supplementary Figure 4B). In human patients, a significant association was found between elevated p53 levels, indicative of 553 mutations, and basal-like breast cancer, which is characterised by CK5 expression (Rakha et al, 2009). In addition to the expression of cytokeratin 5, gene expression analysis on p53 ${ }^{\mathrm{R} 270 \mathrm{H}}$ mammary tumours showed elevated levels of several basal markers including Trp63, Krt17, Cryab, Ptn, Col17a1 and Slug (snai2) (Perou et al, 2000; Liu et al, 2013) (Supplementary Figure 5). This finding is in line with human breast cancer patient data in which p53 missense and truncating mutations are most frequently found in the basal-like subgroup (Cancer Genome Atlas Network, 2012). Thus, p53 null and p53 mutants lead to distinct types of tumours, a feature that is not controlled by FAK.

\section{DISCUSSION}

Genetic alterations in the tumour suppressor protein p53 are frequently observed in breast cancer and are often correlated with FAK overexpression. In this study, we determined the role of FAK in p5 $53^{\text {lox/lox }}$ - and $\mathrm{p} 53^{\mathrm{R} 270 \mathrm{H}_{-}}$-induced spontaneous mammary gland tumour development. We show that mammary neoplasia and hyperplasia are evident in FAK-deleted mammary glands, indicating that FAK does not fully prohibit the initiation of these lesions. However, these lesions contained reduced levels of proliferative 
mammary epithelial cells, while no increase in apoptosis was observed. In conjunction, this led to a significant reduction in mammary tumour incidence in both p53-dependent mammary tumour development models, indicating that FAK is essential for the progression of mammary hyperplasia towards mammary tumours.

Comparison of the $\mathrm{p} 53^{\mathrm{R} 270 \mathrm{H}}$ and $\mathrm{p} 53^{\text {lox/lox }}$ mouse models revealed that the expression of $\mathrm{p} 53^{\mathrm{R} 270 \mathrm{H}}$ mutant resulted in accelerated mammary tumour development. These results indicate that the $\mathrm{p} 53^{\mathrm{R} 270 \mathrm{H}}$ point mutation, apart from having a dominantnegative affect on the wild-type p53 allele, may also acquire gainof-function, which facilitates acceleration of mammary tumour development. Although a gain-of-function for $\mathrm{p} 53^{\mathrm{R} 270 \mathrm{H}}$ was not found by Wijnhoven et al (2007), a recent paper describes that $\mathrm{p} 53^{\mathrm{R} 270 \mathrm{H}}$ enhances the transition from intra-epithelial neoplasia to invasive carcinoma (Heinlein et al, 2008). Interestingly, FAK expression was elevated in $\mathrm{p} 53^{\mathrm{R} 270 \mathrm{H}}$ tumours compared with $\mathrm{p} 53^{\text {lox/lox }}$ tumours, suggesting that the increase in FAK protein contributes to the accelerated tumour development of $\mathrm{p} 53^{\mathrm{R} 270 \mathrm{H}}$ driven tumours.

Interestingly, based on morphology and cytokeratin markers $\mathrm{p} 53^{\mathrm{R} 270 \mathrm{H}}$ and $\mathrm{p} 53^{\mathrm{lox} / \mathrm{lox}}$ mammary tumours have a different appearance. Carcinosarcomas, as observed in p53 $3^{\text {lox/lox }}$ mouse model, are relatively uncommon in humans, but based on their appearance would likely be part of the metaplastic breast cancer subtype. Metaplastic breast carcinoma (MBC) is an umbrella term for a heterogenous group of cancers, which are characterised based on the presence of neoplastic cells with squamous or mesenchymal morphology, such as spindle cells. Metaplastic breast carcinomas frequently harbour mutations in the $\operatorname{Trp} 53$ gene, indicating that the p53 $3^{\text {lox/lox }}$ mouse model potentially mimics a rare human breast cancer subtype (Weigelt et al, 2014). Although FAK depletion inhibited the development of mammary gland tumours in both models, FAK did not affect the differentiation status.

The MMTV-PyMT mouse model for breast cancer has been extensively used to study the role of FAK in mammary tumorigenesis and implicated a role for FAK in breast cancer progression (Lahlou et al, 2007, 2012; Provenzano et al, 2008; Luo et al, 2009; Pylayeva et al, 2009). In line with our findings, mammary gland-specific Fak deletion was shown to reduce the incidence of mammary tumours in the PyMT mice. The studies from Pylayeva et al (2009) revealed that the FAK-deficient PyMTtransformed cells displayed diminished invasive and metastatic capacity. In addition, these cells displayed both growth arrest and apoptosis. After detection by palpation both $\mathrm{p} 53^{\mathrm{R} 270 \mathrm{H}}$ and the p53 ${ }^{\text {lox/lox }}$ tumours grew within a few days to a size that requires sacrifice of the animals. In these animals, we were unable to detect clear metastatic lesions at the macroscopic level, although we can not exclude that small microscopic lesions were present at distant sites. In addition, it was shown previously that FAK deficiency has a severe impact on mammary cancer stem/progenitor cells. Focal adhesion kinase deletion reduced the pool of cancer stem/ progenitors, decreased their self renewal and migration in vitro, and comprised their tumorigenicity and maintenance in vivo (Luo et al, 2009). The reduction in incidence of mammary tumours we observed in our mouse models could be due to decreased numbers of mammary cancer stem/progenitor cells. This fits with the reduced proliferation capacity in preneoplastic lesions in FAK-null mammary glands. Yet, future studies should clarify a role for FAK in the regulation of the survival and/or proliferation of (tumour initiation) stem/progenitor cells. Regardless, the reduced proliferative capacity of preneoplastic cells in the FAK-deleted mammary glands would reduce the change for additional prooncogenic DNA lesions. The differential loss of such a population, which is most likely a dynamic event and progresses over time, may partly explain the bi-phasic effect of the consequences of FAK deletion on mammary gland tumour development. Remarkably, in dept analysis showed that the few tumours that did develop in
$\mathrm{FAK}^{\text {flox/ - }}$ mice were both genetically and phenotypically comparable to $\mathrm{FAK}^{\text {flox } /+}$ tumours. Possibly, at the time of mammary tumour initiation and early mammary tumour development, FAK may not be efficiently deleted yet. Future next generation exonsequencing studies of both preneoplastic and neoplastic material could unveil the underlying genetic events and possible escape mechanisms of the suppression of tumour progression in the absence of FAK.

Our data indicate a functional relationship between p53 and FAK in mammary tumour development. Since p53 regulates FAK expression (Golubovskaya et al, 2008), it would therefore be relevant to correlate the protein levels for FAK in human breast cancer patients expressing the $\mathrm{p} 53^{\mathrm{R} 273 \mathrm{H}}$ mutation (the human equivalent of mouse $\mathrm{R} 270 \mathrm{H})$. In addition, mRNA expression analysis on tumour samples from $\mathrm{p} 53^{\mathrm{R} 270 \mathrm{H}}$ and $\mathrm{p} 53^{\text {lox/lox }}$ tumours could provide more insight into pathways that are differentially regulated in these tumours. These data might shed light on additional functions of the $\mathrm{p} 53^{\mathrm{R} 270 \mathrm{H}}$ mutation. As most human breast cancers express mutant p53 and most tumours express elevated levels of FAK, these patients might respond well to FAK inhibitors, ultimately resulting in reduction of tumour size and/or aggressiveness.

In conclusion, we demonstrate that FAK is important in the spontaneous development of mammary tumours in $\mathrm{p} 53^{\text {lox/lox }}$ and p5 $3^{\mathrm{R} 270 \mathrm{H}}$ mouse models through inhibition of cell proliferation.

\section{ACKNOWLEDGEMENTS}

We thank the personnel of animal facility of Leiden University for excellent animal husbandry and the NKI animal pathology department for their expertise on immunohistochemical staining. We thank dr Erik Danen and dr Marjo de Graauw for critical reading of the manuscript. This work was supported by the Dutch Cancer Society (grant KWF-UL 2007-3860) to BvdW.

\section{REFERENCES}

Cance WG, Harris JE, Iacocca MV, Roche E, Yang X, Chang J, Simkins S, Xu L (2000) Immunohistochemical analyses of focal adhesion kinase expression in benign and malignant human breast and colon tissues: correlation with preinvasive and invasive phenotypes. Clin Cancer Res 6: 2417-2423.

Cancer Genome Atlas Network (2012) Comprehensive molecular portraits of human breast tumours. Nature 490: 61-70.

Coombes KR (2009) ClassDiscovery: classes and methods for "class discovery" with microarrays or proteomics. R package version 2.10.1 edn http:// bioinformatics.mdanderson.org/Software/OOMPA.

Dey A, Verma CS, Lane DP (2008) Updates on p53: modulation of p53 degradation as a therapeutic approach. Br J Cancer 98: 4-8.

De Graauw M, Tijdens I, Cramer R, Corless S, Timms JF, van de Water B (2005) Heat shock protein 27 is the major differentially phosphorylated protein involved in renal epithelial cellular stress response and controls focal adhesion organization and apoptosis. J Biol Chem 280: 29885-29898.

De Vries A, Flores ER, Miranda B, Hsieh H-M, van Oostrom CTM, Sage J, Jacks T (2002) Targeted point mutations of p53 lead to dominant-negative inhibition of wild-type p53 function. Proc Natl Acad Sci USA 99: 2948-2953.

Golubovskaya VM, Conway-Dorsey K, Edmiston SN, Tse C-K, Lark AA, Livasy CA, Moore D, Millikan RC, Cance WG (2009) FAK overexpression and p53 mutations are highly correlated in human breast cancer. Int J Cancer 125: 1735-1738.

Golubovskaya VM, Finch R, Kweh F, Massoll NA, Campbell-Thompson M, Wallace MR, Cance WG (2008) p53 regulates FAK expression in human tumor cells. Mol Carcinog 47: 373-382.

Hainaut P, Hollstein M (2000) p53 and human cancer: the first ten thousand mutations. Adv Cancer Res 77: 81-137. 
Heinlein C, Krepulat F, Löhler J, Speidel D, Deppert W, Tolstonog GV (2008) Mutant p53(R270H) gain of function phenotype in a mouse model for oncogene-induced mammary carcinogenesis. Int $J$ Cancer 122: 1701-1709.

Ilic D, Furuta Y, Suda T, Atsumi T, Fujimoto J, Ikawa Y, Yamamoto T, Aizawa S (1995) Focal adhesion kinase is not essential for in vitro and in vivo differentiation of ES cells. Biochem Biophys Res Commun 209: 300-309.

Ilic D, Kovacic B, McDonagh S, Jin F, Baumbusch C, Gardner DG, Damsky CH (2003) Focal adhesion kinase is required for blood vessel morphogenesis. Circ Res 92: 300-307.

Lahlou H, Sanguin-Gendreau V, Frame MC, Muller WJ (2012) Focal adhesion kinase contributes to proliferative potential of ErbB2 mammary tumour cells but is dispensable for ErbB2 mammary tumour induction in vivo. Breast Cancer Res 14: R36 1-14.

Lahlou H, Sanguin-Gendreau V, Zuo D, Cardiff RD, McLean GW, Frame MC, Muller WJ (2007) Mammary epithelial-specific disruption of the focal adhesion kinase blocks mammary tumor progression. Proc Natl Acad Sci USA 104: 20302-20307.

Lightfoot Jr HM, Lark A, Livasy CA, Moore DT, Cowan D, Dressler L, Craven RJ, Cance WG (2004) Upregulation of focal adhesion kinase (FAK) expression in ductal carcinoma in situ (DCIS) is an early event in breast tumorigenesis. Breast Cancer Res Treat 88: 109-116.

Lim S-T, Chen XL, Lim Y, Hanson DA, Vo T-T, Howerton K, Larocque N, Fisher SJ, Schlaepfer DD, Ilic D (2008) Nuclear FAK promotes cell proliferation and survival through FERM-enhanced p53 degradation. Mol Cell 29: 9-22.

Liu T, Zhang X, Shang M, Zhang Y, Xia B, Niu M, Liu Y, Pang D (2013) Dysregulated expression of Slug, vimentin, and E-cadherin correlates with poor clinical outcome in patients with basal-like breast cancer. J Surg Oncol 107: 188-194.

Luo M, Fan H, Nagy T, Wei H, Wang C, Liu S, Wicha MS, Guan J-L (2009) Mammary epithelial-specific ablation of the focal adhesion kinase suppresses mammary tumorigenesis by affecting mammary cancer stem/progenitor cells. Cancer Res 69: 466-474.

Madan R, Smolkin MB, Cocker R, Fayyad R, Oktay MH (2006) Focal adhesion proteins as markers of malignant transformation and prognostic indicators in breast carcinoma. Hum Pathol 37: 9-15.

Malkin D, Li FP, Strong LC, Fraumeni Jr JF, Nelson CE, Kim DH, Kassel J, Gryka MA, Bischoff FZ, Tainsky MA (1990) Germ line p53 mutations in a familial syndrome of breast cancer, sarcomas, and other neoplasms. Science 250: 1233-1238.

McLean GW, Brown K, Arbuckle MI, Wyke AW, Pikkarainen T, Ruoslahti E, Frame MC (2001) Decreased focal adhesion kinase suppresses papilloma formation during experimental mouse skin carcinogenesis. Cancer Res $6 \mathbf{1}$ 8385-8389.

Moon H-S, Park WI, Choi E-A, Chung H-W, Kim S-C (2003) The expression and tyrosine phosphorylation of E-cadherin/catenin adhesion complex, and focal adhesion kinase in invasive cervical carcinomas. Int J Gynecol Cancer 13: 640-646.

Perou CM, Sørlie T, Eisen MB, van de Rijn M, Jeffrey SS, Rees CA, Pollack JR, Ross DT, Johnsen H, Akslen LA, Fluge O, Pergamenschikov A, Williams C,
Zhu SX, Lønning PE, Børresen-Dale AL, Brown PO, Botstein D (2000) Molecular portraits of human breast tumours. Nature 406: 747-752.

Provenzano PP, Inman DR, Eliceiri KW, Beggs HE, Keely PJ (2008) Mammary epithelial-specific disruption of focal adhesion kinase retards tumor formation and metastasis in a transgenic mouse model of human breast cancer. Am J Pathol 173: 1551-1565.

Pylayeva Y, Gillen KM, Gerald W, Beggs HE, Reichardt LF, Giancotti FG (2009) Ras- and PI3K-dependent breast tumorigenesis in mice and humans requires focal adhesion kinase signaling. J Clin Invest 119: 252-266.

R Development Core Team. R: A language and environment for statistical computing. (Vienna, Austria: R Foundation for Statistical Computing) http://www.R-project.org/.

Rakha EA, Elsheikh SE, Aleskandarany MA, Habashi HO, Green AR, Powe DG, El-Sayed ME, Benhasouna A, Brunet J-S, Akslen LA, Evans AJ, Blamey R, Reis-Filho JS, Foulkes WD, Ellis IO (2009) Triple-negative breast cancer: distinguishing between basal and nonbasal subtypes. Clin Cancer Res 15: 2302-2310.

Srivastava S, Zou ZQ, Pirollo K, Blattner W, Chang EH (1990) Germ-line transmission of a mutated p53 gene in a cancer-prone family with Li-Fraumeni syndrome. Nature 348: 747-749.

Tibshirani R, Chu G, Narasimhan B, Li J (2011) samr: SAM: Significance Analysis of Microarrays. R package version 2.0.

Van Miltenburg MHAM, Lalai R, de Bont H, van Waaij E, Beggs H, Danen EHJ, van de Water B (2009) Complete focal adhesion kinase deficiency in the mammary gland causes ductal dilation and aberrant branching morphogenesis through defects in Rho kinase-dependent cell contractility. FASEB J 23: 3482-3493.

Wagner KU, Wall RJ, St-Onge L, Gruss P, Wynshaw-Boris A, Garrett L, Li M, Furth PA, Hennighausen L (1997) Cre-mediated gene deletion in the mammary gland. Nucleic Acids Res 25: 4323-4330.

Weigelt B, Eberle C, Cowell CF, Ng CKY, Reis-Filho JS (2014) Metaplastic breast carcinoma: more than a special type. Nat Rev Cancer 14(3): 147-148.

Wijnhoven SWP, Speksnijder EN, Liu X, Zwart E, vanOostrom CTM, Beems RB, Hoogervorst EM, Schaap MM, Attardi LD, Jacks T, van Steeg H, Jonkers J, de Vries A (2007) Dominant-negative but not gain-of-function effects of a p53.R270H mutation in mouse epithelium tissue after DNA damage. Cancer Res 67: 4648-4656.

Wijnhoven SWP, Zwart E, Speksnijder EN, Beems RB, Olive KP, Tuveson DA, Jonkers J, Schaap MM, van den Berg J, Jacks T, van Steeg H, de Vries A (2005) Mice expressing a mammary gland-specific R270H mutation in the p53 tumor suppressor gene mimic human breast cancer development. Cancer Res 65: 8166-8173.

This work is published under the standard license to publish agreement. After 12 months the work will become freely available and the license terms will switch to a Creative Commons AttributionNonCommercial-Share Alike 3.0 Unported License.

Supplementary Information accompanies this paper on British Journal of Cancer website (http://www.nature.com/bjc) 